Journal of Teacher Education for Sustainability, vol. 18, no. 2, pp. 75-88, 2016

\title{
The Transformation of Traditional Universities into Entrepreneurial Universities to Ensure Sustainable Higher Education
}

\author{
Veronika Bikse and Inese Lusena-Ezera \\ Liepaja University, Management Sciences Institute, Latvia \\ Baiba Rivza \\ Latvia University of Agriculture, Latvia \\ Tatjana Volkova \\ BA School of Business and Finance, Latvia
}

\begin{abstract}
This paper aims to investigate the experience and to identify the drivers of transforming traditional universities into Entrepreneurial Universities for ensuring sustainable higher education in Latvia. Due to the wide scope, Entrepreneurial University characteristics, the present research study is limited and focuses on the university providing access to students to business incubation facilities, relationships with business incubators for students, as well openness of university to collaboration and knowledge co-creation with its external stakeholders. Analyses of the experiences of universities of Latvia business incubators providing services to students, as well cooperation between higher education institutions (HEI) and local governments and entrepreneurs show that there is a positive trend. In opposite, such a trend can't be observed towards building Entrepreneurial Universities in Latvia over the past 5 years. The results of the survey show that there is a need put higher efforts to assist young entrepreneurs in building cooperation networks and strengthening knowledge co-creation with external stakeholders.
\end{abstract}

Keywords: Entrepreneurial University, student business incubators, entrepreneurship education, Quintuple Helix Model, Sustainable higher education

\section{Introduction}

Nowadays the role of universities is facing rapid change in the context of expansion of their tasks, leading to development of an Entrepreneurial University, creating business incubators for students to ensure sustainable higher education. The importance of an Entrepreneurial University by providing students with new ideas, skills and the ability to think and respond entrepreneurially to societal challenges, enhancing co-creation with external partners is becoming a driving source for achieving sustainable higher education, and it has received considerable attention over the last years. Education as 
sustainability is the mean through which we educate our citizens to the values, opportunities, and choices each person has to develop one's self as an aware, independent, responsible, and active agent of one's own fate and hence contribute to the future of our society (Medrick, 2013).

The traditional university is usually involved in two main activities: teaching and research. A new approach to the role of universities envisages a structural shift from their traditional missions to a third task: the commercialization of new knowledge for economic development (Etzkowitz et al., 2000). Integrating economic and social development into university's mission urges universities towards transformation from being traditional teaching and research universities towards becoming Entrepreneurial Universities (Dino Arnaut. Towards an Entrepreneurial University). Thus universities play an important role in providing the necessary education for future entrepreneurial persons with developed intuitive decision making, the capacity to make things happen autonomously, networking, initiative taking, opportunity identification, creative problem solving, strategic thinking, and self efficacy, upon the ability of an individual to cope with an unpredictable external environment and the associated entrepreneurial ways of doing, thinking, feeling, communicating, organising and learning (The Entrepreneurial University: From concept to action, 2013).

A business incubator is an important tool that can be used by universities to support new start-ups and spin-offs, as well as to build links with industry (EC/OECD, 2012), thus ensuring economic development of certain territories at regional and even national level. In this respect, the task of business incubators is to foster the creation and development of new, innovative, sustainable companies by providing favourable business conditions. An essential condition for business incubator development is to enhance networking with different institutions, ensuring protection of the environment in a broader sense by applying the Quintuple Helix Model, delivering eco-innovation and eco-entrepreneurship that should be processed in such a broader understanding of knowledge, production and innovation (Carayannis and Campbell, 2010; Carayannis et al., 2015). This means that the sustainability context must be central to twenty first century education. Moreover, the approach to business must be just as transformational as the approach to pedagogy. Students need to learn about and develop skills relevant to the emerging green economy not just the old business model of the 20th century, because their innovation and creativity will help the new form of sustainable enterprise (David V. J. Bell, 2016). Education for Sustainability enables people to develop the knowledge, skills, values and competencies that promote sustainable actions and lead to improved quality of life now without destroying the environment for future generations (Besong \& Holland, 2015).

The idea of business incubators emerged in the United States of America in the middle of the last century after the Second World War as a new instrument for reviving abandoned factories and industrial districts, offering new entrepreneurs office premises and resources for shared use. The fastest expansion of business incubators was observed beginning with the 1970 s, owing to the development of service sectors that created the need for more micro-, small and medium enterprises. At present, business incubators are spread worldwide.

In Latvia, the first business incubator (the Latvian Technological Centre) was established in 1993 under the programme of the Latvian Investment and Development Agency. At present, 10 business incubators actively operate under the European Regional Develop- 
ment Fund in 20 Latvian towns; however, in addition to the ones mentioned, there are a number of private initiatives and university-based business incubators (http:/www.liaa. gov.lv/lv/biznesa-abc/biznesa-inkubatori).

In Latvia, as in other European countries, the founders of business incubators are mostly universities, municipalities and entrepreneurs, thereby providing sufficient financial and intellectual resources to successfully implement business incubator projects. Business incubators can help not only new entrepreneurs but also university scientists and academic staff to turn their discoveries and ideas into an economically successful product or services, they can also strengthen cooperation between scientists and entrepreneurs in general.

Nowadays, a significant challenge of the educational system is to create favourable preconditions enabling young people themselves to create jobs, thus preparing students for the modern business world and practices. It requires re-orienting the study process towards entrepreneurship education, involving students in new training modules such as university-based business incubator activities and encouraging them to become entrepreneurs, thereby contributing to personal development, job creation and sustainable economic development.

This paper aims to investigate the experience and to identify the problems related to the transformation of traditional universities into Entrepreneurial Universities for delivering sustainable higher education in Latvia, thus demonstrating higher education institutions commitment to become an Entrepreneurial University.

The questions addressed in this paper are as follows: What are the main characteristics of the Entrepreneurial University? Are there Entrepreneurial Universities in Latvia? What lessons can be learnt from the experience of developing their links with universitybased business incubators, cooperation between regional higher education institutions (HEI) and with local governments and entrepreneurs to deliver sustainable higher education?

\section{What are the Main Characteristics of the Entrepreneurial University?}

In specific literature, a number of different features of an Entrepreneurial University can be found. For example, Dino Arnaut provides the main characteristics of an Entrepreneurial University from different aspects based on views of different authors (Burton, Clark, 2004; Etzkowitz, 2004; Hannon, 2008; Robertson, 2008; Gibb, Haskins and Robertson, 2009). Arnaut points out that "In order to be entrepreneurial, the university must embed entrepreneurship in every part of itself, from its leadership through to its teaching and student impact. It needs to demonstrate excellence in strong leadership at all levels, innovative faculties and a clear, tangible impact on staff, stronger engagement with students in a diversity of learning opportunities, business and the local community, and it needs to demonstrate a long-term commitment of higher education institutions to engaging in enterprise and entrepreneurship, which will consequently help to develop the economy" (Dino Arnaut, 138-139).

Other authors (Guerrero et al., 2015) have summarized characteristics of an Entrepreneurial university based on findings of various authors' publications from 1998 up to 2012. The above-mentioned authors have developed characteristics of an Entrepreneurial University based on six features (Table 1). After summarizing the findings, they concluded that the Entrepreneurial University generates several direct outcomes from teaching, research, and entrepreneurial activities. These outcomes could be transformed 
into a determinant of economic development. In addition, Thorp and Goldstein (2010) identified quite different features of an Entrepreneurial university (Table 1).

More specific characteristics of the Entrepreneurial University, comprising seven features, have been developed by the European Commission's DG Education and Culture in collaboration with the OECD LEED forum. As a result, a Guiding Framework for Entrepreneurial Universities was delivered in 2012 (Table 1).

Table 1

Characteristics of the Entrepreneurial University as Given by the European Commission, OECD (2012) and Holden Thorp and Buck Goldstein (2010) and Maribel Guerrero et al. (2015)

\begin{tabular}{|c|c|c|}
\hline $\begin{array}{l}\text { European Commission's and } \\
\text { OECD LEED forum }\end{array}$ & $\begin{array}{c}\text { Holden Thorp and Buck } \\
\text { Goldstein }\end{array}$ & \\
\hline $\begin{array}{l}\text { 1. Leadership and Governance } \\
\text { 2. Organisational Capacity, } \\
\text { People and Incentives } \\
\text { 3. Entrepreneurship develop- } \\
\text { ment in teaching and learning } \\
\text { 4. Pathways for entrepreneurs } \\
\text { 5. University - business/ } \\
\text { external relationships for } \\
\text { knowledge exchange } \\
\text { 6. The Entrepreneurial univer- } \\
\text { sity as an internationalised } \\
\text { institution } \\
\text { 7. Measuring the impact of } \\
\text { the Entrepreneurial university }\end{array}$ & $\begin{array}{l}\text { 1. It recognizes that liberal } \\
\text { arts education has fuelled } \\
\text { American innovation. } \\
\text { 2. It thrives on big } \\
\text { problems. } \\
\text { 3. It values both innova- } \\
\text { tion and execution. } \\
\text { 4. It places culture ahead } \\
\text { of structure. } \\
\text { 5. It encourages partner- } \\
\text { ships between academics } \\
\text { and entrepreneurs. }\end{array}$ & $\begin{array}{l}\text { 1. Its organizational adaptation } \\
\text { to environmental changes (Clark, } \\
\text { 1998), } \\
\text { 2. Its managerial and governance } \\
\text { distinctiveness (Subotzky, 1999), } \\
\text { 3. New activities oriented to the } \\
\text { development of entrepreneurial } \\
\text { culture at all levels (Kirby, } \\
\text { 2002), } \\
\text { 5. Its contribution to economic } \\
\text { development with the creation } \\
\text { of new ventures (Chrisman } \\
\text { et al., 1995), } \\
\text { 6. The commercialization of } \\
\text { research (Jacob et al., 2003). }\end{array}$ \\
\hline
\end{tabular}

Summarising the research done on the characteristics of the Entrepreneurial University by various authors, it is important to mention that there are several attempts to identify the features of an Entrepreneurial University in literature. However, there is still no consensus among authors about the main characteristics of the Entrepreneurial University. Consequently, further comparative studies and consideration of the practical aspects of the Entrepreneurial University could be problematic.

Our position on the features of an Entrepreneurial University identified by various authors could be supported in general. At the same time, the authors consider that more authentic and more practical are the features of an Entrepreneurial University developed by the EC and the OECD in a Guiding Framework (2012). It has been argued that as a self-assessment tool, the framework has the simple purpose of helping universities identify their current situation and potential areas of action, taking into account their local and national environments (EC/OECD, 2012).

According to the Guiding Framework, there are several activities which are established and managed by a university in order to justify the status of Entrepreneurial University:

- an entrepreneurial strategy;

- the formation of a model for coordinating and integrating entrepreneurial activities at all levels across the university and a wide variety of funding sources, including investment by external stakeholders; 
- investment in staff development to support its entrepreneurial agenda;

- stimuli and support for the development of entrepreneurial mind-sets and skills throughout the entrepreneurship education by using a variety of teaching methods including: case studies, games and simulation, real experience reports by start-ups and studies of business failure;

- provision of opportunities to experience entrepreneurship: free access to business incubators, science parks, laboratories, research facilities and IT services, coaching, mentoring, training and access to financing and taking part in entrepreneurial activities with business/the external environment;

- knowledge exchange and relationships with the public sector, regions, businesses, alumni, professional bodies etc.;

- support for international mobility and active participation in international networks by its staff and students;

- regular monitoring and evaluation of the impact of entrepreneurship education, knowledge exchange activities and start-up support activities (EC/OECD, 2012).

Thus, a university is entrepreneurial when it employs a holistic approach to ensuring the implementation of all the above-mentioned activities. As a result, it is any university that undertakes entrepreneurial activities with the objective of improving regional or national economic performance (Philpott et al., 2011).

The Guiding Framework may well serve as a starting point to investigate the application of activities by universities to comply with characteristics of an Entrepreneurial University. Due to the wide scope of the characteristics, the present research study is limited and focuses on the following characteristics of an Entrepreneurial University: the university has strong links with student incubators, science parks etc. and provides access to business incubation facilities; the university is committed to collaboration and knowledge exchange with its external stakeholders; the university is a driving force for entrepreneurship development and can play an important role in development of sustainable higher education.

\section{Research Methodology and Participants}

The research methodology implemented for this study is based on the theoretical concepts of an Entrepreneurial University and its links with student business incubators and development of sustainable higher education.

In order to determine the extent of collaboration and knowledge exchange with universities and the external stakeholders, a survey was conducted (in October 2015). The survey was conducted by creating a questionnaire. Questionnaires were given to the enterprise managers incubated and developed in the Kurzeme Business Incubator. The survey was conducted electronically by using the platform: docs.google.com/forms. A questionnaire consisted of 28 questions. The content included open and closed questions. In total, 129 managers of enterprises that are being and have been incubated in the Kurzeme Business Incubator were invited to participate in the survey. Replies were received from 80 entrepreneurs or $62 \%$ of the total.

The data of the survey was processed by the authors within the national research programme EKOSOC-LV at the Institute of Management Sciences of the University of Liepaja. 
To obtain a deeper insight into the research problem and the interaction amongst an Entrepreneurial University, student business incubators and development of sustainable education, the experience of university-based business incubators in Latvia is analysed in this research.

There are 57 public and private higher education institutions (and two affiliates of foreign universities) in Latvia, including 26 colleges and 6 universities. Five universitybased business incubators operate at universities in Latvia. These universities are as follows: Riga Technical University, the University of Latvia, Turiba University, BA School of Business and Finance, Riga International School of Economics and Business Administration (RISEBA). Five additional business incubators have been established in cooperation with regional higher education institutions and operate outside the remit of the institutions. The business incubators provide their participants with the environment needed for entrepreneurship: premises; accounting and communication services; consultancy services in marketing, product technology improvement, legal and business matters provided by experts; Internet portal hosting; mentoring; the Internet, stationery and office equipment (printers, copiers and scanners) etc.

\section{The Experience of University-based Business Incubators in Latvia for Development Sustainable Higher Education}

University-based business incubator activities focus on how to provide opportunities for staff and students to take part in entrepreneurial activities during the study process; (EC/OECD, 2012) to make strong links with external stakeholders and entrepreneurs to serve in a mentoring role, helping a university to identify and further develop commercialization opportunities and other initiatives (The Innovative and Entrepreneurial University: Higher Education, Innovation \& Entrepreneurship in Focus, 2013). Thus, to ensure the integrity of theory and practice in the study process, enabling students to learn by doing and to demonstrate their skills in a particular activity through searching for an innovative approach to tackling economic problems. Another important precondition is the creation of an environment contributing to creative thinking which would promote the generation of new ideas that fascinate, make individuals act, and shape their lifestyle. According to the survey by the Global Entrepreneurship Monitor, 87\% of EU respondents who have started or taken over a business say that having an appropriate business idea was important to their decision to do so (European Commission, 2012).

There are good practices in Latvia for implementing the Entrepreneurial University approach which considerably contributes to providing strong links with business incubators during the study process. For example, the student business incubator of Turiba University was founded in 2006. At present, about 80 future and new entrepreneurs are involved in it. The university has started implementing a study approach based on practical education. The future professionals who study in the professional undergraduate, master or doctoral programme of all the faculties are offered practical studies in a business incubator where, along with acquiring knowledge on entrepreneurship, they also implement their business ideas by creating enterprises. The university provides premises and a mentor's advice - all that is necessary for founding and managing an enterprise. Students are given an opportunity to establish an enterprise by uniting in teams or to establish sole proprietorship. If the students work in teams in the process of establishment 
of enterprises, each of them has to choose to perform some steps of the activity so that each can learn management, marketing, finance and accounting and other entrepreneurial skills. For successful entrepreneurship, along with practical activities, students hold meetings with experienced entrepreneurs, attend lectures, independently study special literature, learn to process information - to assess, analyse and systemise it, and to find creative solutions in order to enhance the services offered by their enterprise and to ensure its expansion. Thus students develop a wide range of valuable skills including business-plan development, marketing, networking and financing, and gain experience in working in a team, they jointly plan, conduct, and manage their work, they learn to cooperate, agree, make compromises, jointly make decisions and connections with local business leaders (http://www.turiba.lv/lv/dzive-augstskola/biznesa-inkubators/116/).

A student business incubator was established also at the University of Latvia (LU) Faculty of Economics and Business Management in 2013. This was aimed at providing support to University of Latvia students and to make them interested in starting and expanding a business. Within an academic year, the business incubator offers two options for students of all the LU faculties:

- Those who intend to found their own enterprise in the future, to materialise and develop their business idea into a finished product and to become confident in their abilities and ideas are given the opportunity to study in the programme Student Entrepreneurial Spirit;

- Those who already have a business idea the opportunity is given to work in the business incubator to found their own enterprise.

The programme Student Entrepreneurial Spirit is implemented within the study course Economics of Entrepreneurship in which students, along with acquiring theoretical knowledge, may practically act and implement their business idea by founding an enterprise. Students working in the business incubator acquire the knowledge needed for entrepreneurship and build their skills and experience in developing a product, they also participate in a grant contest and establish their own enterprise. In the academic year 2015/2016, 175 students from various LU faculties have been taking this programme. They work in teams of five students, design a business plan, interview potential customers, create and develop their business idea and materialise it in new innovative products. A grant contest is held at the end of the academic course. An experienced entrepreneur commission evaluates the contestants. Four teams whose products obtain the highest scores are granted $€ 6000$ each for starting up a business, as well as the opportunity to work in the LU Student Business Incubator for an extra four months.

However, those students who already have a business idea and are working in the business incubator can found their own enterprise. In October 2015, the business incubator admitted 240 students from various LU faculties and established 60 teams. The students had to develop a new innovative product within three months and found their own enterprise over the next nine months. To build up skills in entrepreneurship, the students work in teams, hold mastermind group meetings and participate in individual coaching sessions with Riga Coaching School coaches. During the incubation period, all the students are provided with premises, access to a prototyping studio and facilities for taking videos and their processing, a multimedia centre, an enterprise data centre, an Internet portal and mentoring consultations on various business-related issues (http://www.biznesainkubators.lu.lv/par/pakalpojumi/). 
The new approach to studying entrepreneurship which is essentially different from traditional academic studies is applied in Riga Technical University (RTU). Within the course, Economics of Entrepreneurship based on an "Opportunity-oriented problembased learning model (OOPBL)", students learn by doing and reflecting, based on their experience, and by solving real life problems in order to create new products and services that could be commercialised. The studies according to the OOPBL model were provided for second year bachelor students $(\mathrm{N}=85)$. The students worked in teams of 3-6 to get used to working together and realising all the steps of the OOPBL model in order to find some new opportunities for the perfection of the product/service-to-be and for enhancing its potential of commercialisation. The study course was realised in collaboration with three entrepreneurs who represented different fields of business. They shared their experience and also participated in the evaluation of the final presentations of the students and the prototypes of the products/services elaborated by them (Oganisjana, Laizans, 2015). Further, the students are given the opportunity to implement their business ideas, working in the Student Business Incubator which has been functioning at RTU since 2010. The students - future entrepreneurs - are provided with the necessary support for starting a business, usually for a year, i.e. the incubation period (http://karjera.rtu.lv/lv/ieraksts/rtu-studentu-biznesa-inkubators).

Nowadays, sustainable higher education is one of the key factors fostering economic growth in the country through collaboration with internal and external stakeholders. An important prerequisite is the formation of links among universities, business incubators and the economy, particularly links with the environment of the creative industries, as it can ensure much a higher value-added for any business. In this respect, valuable experience has been accumulated at Riga International School of Economics and Business Administration (RISEBA). It delivers a study programme in audio-visual media arts and architecture in cooperation with professionals of the creative industries. In 2013 the Creative Business Incubator was established to ensure the unity of theory and practice and to give students an opportunity to realise their creative ideas in particular projects and to create conditions for business start-up already during their studies. At present, it is developing nine business ideas in the field of creative industries, social entrepreneurship and consultancy. The incubator's motto is 'Create and Start!' This means contributing to the creativity of students and their wish to start up a business. The business incubator is actually the entire university - the university's premises and infrastructure, its creative potential and its students and academics. That is why the incubator's name reflects the synergy of creativity and the business environment. There is strong cooperation between the Creative Business Incubator and the students and academics of RISEBA creative study programmes to assist in developing products with higher value-added in design, IT and other creative service industries for enterprises to be incubated. It is envisaged that the incubator will have an idea laboratory and a service centre where services are provided to new entrepreneurs by RISEBA students and academics (http:/www.riseba.lv/ lv/riseba-radosais-biznesa-inkubators/inkubatora-dalibnieki.html; http://nekrize.lv/ augstskola-ka-vienots-biznesa-inkubators/).

The examples mentioned prove that it is essential for higher education institutions to provide student business incubator services. It provides conditions for the study process to be designed in a way that, along with acquiring knowledge, students can develop their unique abilities by using the possibility of working practically during the entire period of their studies. This allows them to express themselves in a creative way, to make 
decisions and draw conclusions independently, to develop their ability to take responsibility and the initiative and not to be afraid of the unknown, and builds confidence in achieving what was intended (Bikse et al., 2013).

Establishing student business incubators is not a sufficient prerequisite towards building an Entrepreneurial University. A complex approach to the transformation from a traditional teaching university to an Entrepreneurial University involves: starting to redefine the university's mission statement, developing strategic development plans, implementing the necessary organizational changes, introducing new training modules of entrepreneurial education and involving students in the new organisational mechanisms such as university-based business incubators, technology transfer contact offices and innovation centres, and developing the networks among them. Otherwise it is a too narrow and fragmented approach towards creating an Entrepreneurial University and not systematic by nature. The educational system mainly focuses on preparing highly qualified professionals to become qualified employees in a certain field, rather than developing an individual's entrepreneurial competences along with educating them in a certain speciality so that young individuals are ready to start their business, becoming employers. The transformation of traditional universities into Entrepreneurial Universities is beneficial not only for universities themselves, students and graduates, but also for society in large.

\section{A Survey of Cooperation between the New Entrepreneurs of Kurzeme Business Incubator and Universities and Municipalities, and of Attitudes to Preserving the Environment}

One of the fundamental characteristics of an Entrepreneurial University is the collaboration with the external environment and its external stakeholders - with communities, local organisations, local government chambers of commerce and alumni (EC/OECD, 2012). Cooperation with business incubator alumni - new entrepreneurs who incubated their businesses in an incubator and are working independently - is of great importance. The gain is mutual. For the university, the new entrepreneurs' experience that can be used in entrepreneurship education is important. They could be engaged as visiting lecturers, in designing and enhancing development of study programmes, and as providers of internships for students at their enterprises. The new entrepreneurs, in their turn, would not lose their links with universities and would gain from cooperation with researchers and the commercialisation of their innovative research into new goods or services, technologies, solutions and processes, as universities are responsible for knowledge creation and transfer and for potential entrepreneurs' education (Norat RoigTierno et al., 2015). National, regional, and local governments are also providing support to facilitate university and business interactions, such as designing regulations, laws, policies, and programmes that promote responsible innovation and economic development goals (The Innovative and Entrepreneurial University: Higher Education, Innovation \& Entrepreneurship in Focus, 2013).

To identify what kind of cooperation and contact exists between new entrepreneurs and universities and local governments, and their attitudes to preserving the environment, a survey of entrepreneurs that are being and have been incubated at Kurzeme Business Incubator was conducted, as this incubator is one of the best in Latvia. 
The key function of Kurzeme Business Incubator (hereinafter KBI) is to contribute to the formation of new and innovative enterprises by providing the enterprises with premises, infrastructural services and consultancy in basic issues of entrepreneurship for four years, so that they become capable of operating independently and being financially self-sufficient. The purpose of KBI is to foster and support eco-entrepreneurship in certain industries of the national economy, in the region this activity is particularly important. Since its establishment in 2009, KBI has been one of the largest in Latvia in terms of the number of enterprises being incubated and the ones that have been incubated in the past. For example, 31 new enterprises are operating in the incubator, and 129 had already been incubated and left KBI in 2014.

Most the respondents were men, comprising 52\%, while women accounted for $48 \%$. The respondents were quite young with an average age of 30 years. Those holding a bachelor's degree were $25 \%$, those with a master's degree made up $75 \%$. The respondents' employment status was as follows: $75 \%$ were micro-enterprise managers and $25 \%$ were small enterprise managers.

An analysis of the kinds of goods and services produced by the enterprises represented in the survey $(n=80)$ shows that the assortment is diverse. The largest group of entrepreneurs provided IT services (16\%) involving the production of software, websites etc. This was followed by art, design, entertainment and recreational services $(10 \%)$, as well as the manufacture of food products and beverages (also 10\%). The entrepreneurs also produced unique (innovative) construction materials, wood-processing products and furniture, organic food for babies, confectionary goods and other kinds of products as well as advertising and marketing services.

According to the survey, more than half of the entrepreneurs questioned sold their products in Latvia (57\%), mainly within their municipality. This could be partly explained by the fact that in the Kurzeme region, as in the whole of Latvia, the foundations of the economy are composed of small and medium enterprises. The entrepreneurs questioned quite actively used the markets of the Baltic States (selling 29\% of their products there) and of the EU Member States (14\%). In this way, they offset the relatively small market of Latvia.

The survey $(n=80)$ indicated that the entrepreneurs very rarely cooperated with universities in the field of further education, training placements for students, enhancement of the study process/programmes, and the attraction of professionals from universities. However, the majority of the respondents pointed out that their enterprises had never cooperated in knowledge transfer and innovation issues and in financing research studies, and had never participated in research projects and university career day activities or in granting scholarships, nor had they ever acted as sponsors.

During the survey, respondents were given the opportunity to answer an open question about whether they wished to cooperate with universities. Two thirds of the 53 entrepreneurs said they would cooperate with universities with pleasure. The entrepreneurs most often stated that it was important to provide training placements and to cooperate with universities concerning the further education of their employees and the attraction of employees from the universities. They wished to have stronger cooperation in implementing the study process to contribute to the preparation of professionals needed for the local region, and also to contribute to cooperation in the fields of scientific and practical research (student/doctoral student papers) and the development of new products. From this we can conclude that universities should collaborate much more 
actively with new entrepreneurs, maintain regular contact with them and organise activities that integrate their experience and expertise into entrepreneurship education and start-up support services (EC/OECD, 2012).

An important task of the national government is to foster entrepreneurship in the region, as the state cannot be strong if some its smaller links are not viable. The survey showed that new entrepreneurs had almost no regular cooperation with local governments, and the same situation was observed for their cooperation with universities. However, their cooperation with local governments was relatively better, as they had some cooperative activities on rare occasions. Of the new entrepreneurs surveyed, $62.5 \%$ had had some opportunity to receive financial or other kinds of assistance from local authorities; $52.5 \%$ of the respondents engaged in joint activities, and some maintained business contacts, as tackling problems were important for both sides (Table 2).

Table 2

Cooperation between KBI Enterprises and Local Governments ( $\%$ of $n=80$ )

\begin{tabular}{lccc}
\hline & Never & Rarely & Regularly \\
\hline Business contacts, tackling problems important to both sides & 75 & 25 & - \\
\hline $\begin{array}{l}\text { Contribution to knowledge transfer, innovation and cooperation } \\
\text { with universities }\end{array}$ & 100 & - & - \\
\hline Financial and other kinds of support to new entrepreneurs & 37.5 & 62.5 & - \\
\hline Participation in the preparation of new entrepreneurs & 100 & - & - \\
\hline Engagement of new entrepreneurs in joint activities & 43.8 & 52.5 & 3.7 \\
\hline $\begin{array}{l}\text { Joint implementation and control of the environmental } \\
\text { management system }\end{array}$ & 83.7 & 16.3 & - \\
\hline Contribution to the production of eco-innovative products & 88.8 & 11.2 & - \\
\hline
\end{tabular}

As seen in Table 2, the respondents had never contacted local governments in tackling such important problems as the preparation of new entrepreneurs, knowledge transfer, innovation, and cooperation with universities. The respondents similarly rated the role of local governments in the production of eco-innovative products.

The analysis performed leads to a conclusion that business incubators must be persistently interested in new entrepreneurs and in helping them. In the authors' opinion, the operation of business incubators could be developed as a university-based incubator and as well as an organisational unit of municipalities established in cooperation with Universities thus ensuring broader access to municipality and university infrastructure and financial resources. In this case, municipalities would have broader base for support of an innovative businesses and economic growth in their region.

Nowadays, as significant global climate changes are observed, affecting the surrounding environment, an essential global problem is the preservation of the environment; therefore, it is important to take care of it according to the principles of the Quintuple Helix Model. In this respect, the respondents were asked to answer a question about their attitude to the preservation of the environment. The respondents' replies are summarised in Figure 1.

From this survey the authors found that the business incubator's (KBI) entrepreneurs cared about the environment through carrying out a number of environmental protection and improvement activities at their enterprises. Printing documents in economy mode was practised at all the enterprises. Of the enterprises, $77 \%$ used environmentally friendly 
paper and $54 \%$ contributed to the recycling of paper. However, not a single enterprise sorted its waste, and almost $19 \%$ of the entrepreneurs did not implement any environmental protection activities and measures at their enterprises.

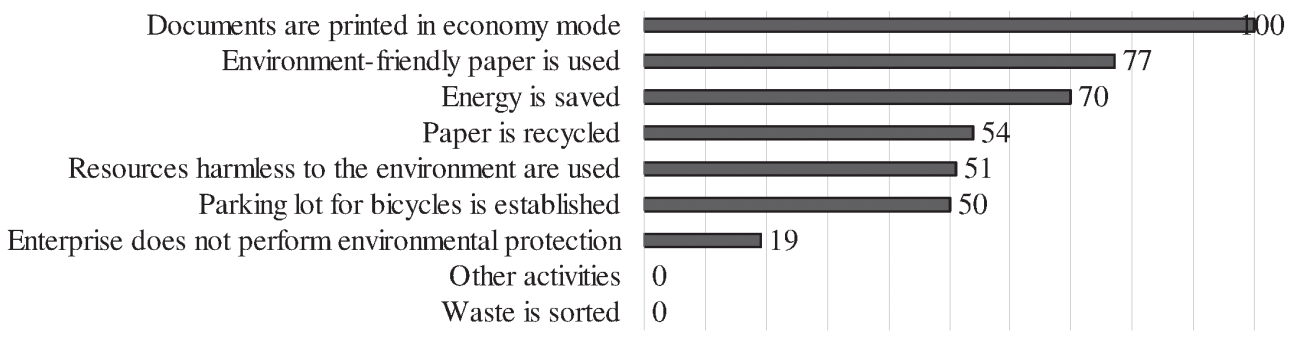

Figure 1. Respondents' replies concerning their attitude to the preservation of the environment ( $\%$ of $n=80$ )

\section{Conclusions}

The research findings show that the transformation of traditional universities into Entrepreneurial Universities to ensure sustainable education in Latvia is at an early stage. The authors conclude that Latvian university-based business incubators have been significantly developed over the past 5 years and are now working well and making efforts towards becoming Entrepreneurial Universities: starting the introduction of new training modules of entrepreneurial education and involving students in the universitybased business incubators activities. The present research findings show that Turiba University, the University of Latvia, Riga Technical University and RISEBA were the most successful in implementing new training modules and demonstrated commitment towards building an Entrepreneurial University. The rest of the higher education institutions are considering transformation towards becoming an Entrepreneurial University, as it is vital to achieve sustainable economic growth in their region.

One of the fundamental characteristics of an Entrepreneurial University is the collaboration with external stakeholders, particularly young entrepreneurs, as they need mentor advice and business contacts the most of all. However, the present research on the cooperation and contacts of the entrepreneurs of KBI with universities and local governments indicates that it is a very rare phenomenon or does not happen at all. In contrast, a positive fact is the respondents' care about the preservation of the surrounding environment: the respondents had carried out several environmental protection and improvement activities at their enterprises.

Overall, the authors can conclude that the contribution of the Latvian universities and student business incubators to ensure sustainable education is essential. In cooperation with business incubators, the universities contribute to the engagement of new entrepreneurs in business; incubated enterprises create new jobs and develop products of various kinds, and these in turn play a considerable role in the sustainable higher education development. Nevertheless, according to the survey, new entrepreneurs need assistance in creating networks of cooperation with various institutions, particularly local governments, as local government support as well as cooperation with universities - 
upon which knowledge transfer to production, innovation and eco-entrepreneurship is dependent - are important to the new entrepreneurs, nowadays the most important prerequisite for economic growth.

\section{Acknowledgments}

The preparation of the paper was supported by the National Research Programme 5.2. Economic Transformation, Smart Growth, Governance and Legal Framework for the State and Society for Sustainable Development - a New Approach to the Creation of a Sustainable Learning Community, Project EKOSOC_LV.

\section{References}

Besong, F. \& Holland, C. (2015). The dispositions, abilities and behaviours (DAB) Framework for profiling learners' sustainability competencies in higher education. Journal of Teacher Education for Sustainability, 17(1), 5-22.

Bikse, V., Rivža, B., \& Brence, I. (2013). Competitiveness and quality of higher education: Graduates' evaluation. Journal of Teacher Education for Sustainability, 15(2), 52-66.

Carayannis E G., Campbell D F J. and Orr Barron J. (2015). Democracy and Environment as References for Quadruple and Quintuple Helix Innovation Systems. EGU General Assembly 2015; p. 17: EGU2015-15497-1.

Carayannis E G. \& Campbell DFJ. (2010). Triple Helix, Quadruple Helix and Quintuple Helix and how do knowledge, innovation and the environment relate to each other? A proposed framework for a transdisciplinary analysis of sustainable development and social ecology. International Journal of Social Ecology and Sustainable Development, 1(1), 41-69.

David V. J. Bell. (2016). Twenty first entury education: Transformative education for sustainability and responsible citizenship. Journal of Teacher Education for Sustainability, 18(1), 48-56.

Dino Arnaut. Towards an Entrepreneurial University. University of Zenica, Bosnia and Herzegovina. Retrieved January 20, 2016, from http:/www.emuni.si/press/ ISSN/1855-3362/3 135-152.pdf

EC/OECD. (2012). A Guiding Framework for Entrepreneurial Universities. Final version 18 December 2012. Retrieved December 3, 2015, from http://www.oecd.org/site/ cfecpr/EC-OECD\%20Entrepreneurial\%20Universities\%20Framework.pdf

Etzkowitz H., Webster A., Gebhardt C., Brance R., \& Cantisano T. (2000). The future of the University and the University of the future: Evolution of ivory tower to entrepreneurial paradigm. Research Policy, 29(2), 313-330.

European Commission. (2012). Entrepreneurship in the EU and beyond. Flash Eurobarometer Report 354. Retrieved February 9, 2016, from http://ec.europa.eu/ public_opinion/flash/fl_354_en.pdf

Guerrero M., Cunningham JA., \& Urbano D. (2015). Economic impact of entrepreneurial universities' activities: An exploratory study of the United Kingdom, Research Policy, 44, 748-764. 
Medrick, R. (2013). A pedagogy for sustainability education. The Journal of Sustainability Education (JSE). Retrieved November 8, 2016, from http://www.jse dimensions.org/wordpress/content/a-pedagogy-for-sustainability-educa

Norat Roig-Tierno, Joaquín Alcázar, \& Samuel Ribeiro-Navarrete. (2015). Use of infrastructures to support innovative entrepreneurship and business growth. Journal of Business Research, 68(11), 2290-2294.

Oganisjana K. \& Laizans T. (2015). Opportunity-oriented problem-based learning for enhancing entrepreneurship of university students. Procedia - Social and Behavioral Sciences, 213(1), 135-141.

Philpott K., Dooley L., O’Reilly C., \& Lupton G. (2011). The entrepreneurial university: Examining the underlying academic tensions. Technovation, 31(4), 161-170.

The Entrepreneurial University: From Concept to Action. (2013). National Centre for Entrepreneurship in Education (NCEE), p. 59. Retrieved December 9, 2015, from http://ncee.org.uk/wp-content/uploads/2014/06/From-Concept-To-Action.pdf

The Innovative and Entrepreneurial University: Higher Education, Innovation \& Entrepreneurship in Focus (2013). U.S. Department of Commerce. The Office of Innovation and Entrepreneurship at the Economic Development Administration. Retrieved November 8, 2015, from http://www.clemson.edu/ces/departments/automotiveengineering/documents/cuicardeptofcommerce2013.pdf

Thorp H. and Goldstein B. (2010). The Entrepreneurial University. Retrieved January 19, 2016, from https:/www.insidehighered.com/views/2010/09/27/thorp

Internet resorces

http://www.biznesainkubators.lu.lv/par/pakalpojumi/ [Accessed: 10-Feb-2016]

http://www.riseba.lv/lv/riseba-radosais-biznesa-inkubators/inkubatora-dalibnieki.html

[Accessed: 12-Jan-2016]

http://nekrize.lv/augstskola-ka-vienots-biznesa-inkubators/ [Accessed: 14-Jan-2016]

http://www.izm.gov.lv/lv/izglitiba/augstaka-izglitiba/augstakas-izglitibas-iestades

[Accessed: 13-Jan-2016]

http://www.liaa.gov.lv/lv/biznesa-abc/biznesa-inkubatori [Accessed: 05-Dec-2015]

http://www.turiba.lv/lv/dzive-augstskola/biznesa-inkubators/116/ [Accessed: 18-Nov2015]

http://karjera.rtu.lv/lv/ieraksts/rtu-studentu-biznesa-inkubators [Accessed: 28-Feb-2016]

Correspondence concerning this paper should be addressed to Veronika Bikse, Liepaja University, Liela iela 14, LV-3401, Latvia. Email: vbikse@lu.lv 